\title{
ALTERNATIVE ACTIVITIES DURING A PANDEMIC PERIOD IN THE SPHERE OF CULTURAL INSTITUTIONS
}

\author{
Michaela Škorupová \\ Department of Media and Communication studies \\ Paneuropean University in Bratislava \\ 10 Tematínska, Bratislava, Slovakia, 85105 \\ xskorupova@paneurouni.com
}

\begin{abstract}
Taking a broad-based view on the global health crisis, this paper examines the feasibility of cultural sector reaction on radical changes on an unexpected situation with an unknown deadline.

The paper summarized the theoretical basis in public relations, presented by Slovak, Czech and foreign authors that explain the meaning, aims and value of PR in the cultural sector. It refers to three basic goals of PR - building an image, routine publicity and crisis PR. The author emphasizes on signification settings of effective communicative tools in new circumstances between cultural organizations and audiences. The aim of this paper is to analyze, how organizations in the cultural sector in Slovakia use available tools to sustain existing audiences and at the same time how to attract new target groups by digital PR tools during the pandemic period. The objects are examined in the paper - theatres, galleries, and philharmonic orchestra in Slovakia. The methodology of this study will be addressed through analytical study. This will be revealed through discussion, investigation, analysis that can be detected through detailed content interrogation of the objects, elements and structure of the content of this study. The content of this article is intended for other cultural organizations that strategically plan their activities in digital form in the future.
\end{abstract}

Keywords: marketing, public relations, the art, culture, Slovak National Theatre, cultural institutions, pandemic, culture.

DOI: 10.21303/2504-5571.2020.001324

\section{Introduction}

People have always spent their leisure time, participating in cultural events. Motivational factors are various: social hedonism and aesthetic experience, social status retaining in a particular community, and the others. In recent months there have been noticeable changes in the way how people spent their leisure time. In several countries the government has taken a ban on organizing cultural events. It describes economical and cultural consequences within pandemic weeks. The spreading coronavirus actively affect the lives of people all over the world and economically disadvantage cultural organizations.

The cultural sector is one of the most vulnerable sectors during the quarantine period. Organizations are economically dependent on the government and on income from consumers. During a pandemic, culture stagnates and declines financially. Artists are having a hard time and culture is disappearing from people's lives. Cultural organizations had to take actions, and for a short time are forced to think about how to strategically change their communication channels and keep their supporters. The results are alternative new forms of art presentation by artists and institutions through new media. Even in crisis situations for artists and cultural organization, it is essential to communicate with the public and potential audiences. There was a struggle to keep the audiences in unconventional forms. The paper analyzes the activities of cultural organizations on this problem in Slovakia.

The pandemic had unexpected adverse effects on the overall functioning of the institution. An empty auditorium, theatres without visitors, concerts without audiences. Effective crisis management is excluded for risk, assessment and response to crisis situations. Events that originate in the organization reflect the risk of PR.

Crisis PR has the primary position in the communication mix. The author of the study, Ms. Johnova draws attention to the connection between cultural organizations and public support, she emphasizes the fact, that it is important to have an open dialogue with cultural consumers. Slovak organizations in the cultural sector confronted this problem responsibly and actively, supported the idea of spreading cultural awareness even in hard economic situations [1, p. 223]. 
The aim of this paper is to analyze, how organizations in the cultural sector in Slovakia use available tools to sustain existing audiences and at the same time how to attract new target groups by digital PR tools during the pandemic period. This will be revealed through discussion, investigation, analysis that can be detected through detailed interrogation of the objects, elements and structure of the content of this study. The content of this article is intended for other cultural organizations that strategically plan their activities in digital form in the future.

\section{The position of $P R$ in cultural sector}

Marketing communication is characterized by four elements: advertising, PR, sales promotion and direct marketing [1, p. 45].

Many theorists define PR harmful. Gordon [2] characterized PR as managed control in order to build good relationships and understanding between the organization and the audiences. Other theorists represent an opinion, that the main task of public relations is to manipulate public opinion within the organization [2]. Public relations is appropriate for analyzing and verifying relationships, reputation or attendance of a cultural entity. Therefore, the existence of this sphere in marketing is higher than just control. How to look for possible elevators, Henry Ford and Bill Gates, their marketing skills and data are shared.

„If I had the last dollar in my pocket, I'd have the last one for advertising”- Henry Ford.

„If I had one dollar left, I'd spend it on PR”-Bill Gates.

Public cultural organizations are financed from the state budget, the financial resources are not sufficient to carry out more activities, so they need effective marketing, PR and especially income from commercial activities for management and promotion.

Communication tools, aimed at disseminating awareness of cultural events in cultural institutions are, for example, openings, press conferences, ceremonial openings of exhibitions with the participation of artists, curators, experts, sponsors and representatives of state or local media. At present, we also have the latest technological advances in the technology tools. The Internet, blogs and social media can help promote it. It is important, that the media are chosen correctly at the venue to ensure that potential candidates learn more about the cultural event. It is PR that can play a key role in attracting new clients of cultural institutions and can condition their attendance. For cultural and non-profit organizations, PR is the cheapest and most effective form of marketing communication. In the past, exhibitions, based on their own collections and curatorial interests, were sufficient for galleries and museums, today they have to think about the interests of consumers and try to meet their expectations. Value-added experiences, personalized to visitors needs, are required by consumers.

Groups, important for cultural institutions, are mainly visitors, donors, state and local government, sponsors, media. According to Ms. Johnova, public relations can achieve three basic goals in the cultural sphere [1, p. 222-223]:

1. Creating an image - building trust with its recipients is important.

2. Routine publicity - takes place continuously.

3. Crisis PR - in a situation that needs to be addressed operationally, openly and responsibly.

The creation of an image depends on the intensity of communication between the cultural organization and the public. In contrast to advertising, PR is advantageous in that it is directly linked to the human factor and specific groups of potential people, interested in culture [3].

An image depends on the intensity of communication between the cultural organization and the public. In contrast to advertising, PR is advantageous in that it is directly linked to the human factor and specific groups of potential people, interested in culture.

„Compared to advertising, they tend to be more trustworthy, less violent and interactive for customers. This is because a substantial part of PR plays a dialogue between institutions and groups (activists, donors, partners, target recipients, legislators and control bodies or journalists)" [3]. 
If we approach the second point of the main goals of PR activities, Světlík divides them on:

- publicity;

- organizing events;

- internal communication;

- lobbying;

- sponsorship;

- corporate identity [4].

Bačuvčík categorizes PR resources into two simple structures according to target groups means of individual action and group action. The division is a priority, especially in terms of whether the institution aims to address individuals or groups. The means of individual action are e. g. interviews or messages, sent internally or externally to another addressee. Bačuvčík emphasizes the very attitude of employees within the organization to the functioning of the entire institution, as their opinions are a priority for a positive impact on the public. This is how he perceives personal conversations, which should lead to the natural spread of the name and image of the organization towards the general public. Reports, sent outside the institution, are addressed primarily to journalists, reviewers, the media, sponsors, subscribers, and other stakeholders. Moving on to mass activities, "experience" and "information" are some of the highest values among a targeted audience. Bačuvčík considers all press materials (brochures, posters, leaflets, newsletters, annual reports, magazines, or PR reports ...) to be a means of mass public relations ... and also emphasizes the "event" strategy, which includes open days, workshops, professional seminars and conferences, etc. We do not have to take the event itself "only" as one of the communication tools. The most important function of event marketing is to create a history by attracting people to a synergistic activity, which is defined by the organization and its goals [5].

Communication methods in culture are mainly related to the goal of not only gaining the customer, but also retaining it. Various combinations of communication methods are used, focusing "primarily on public relations and the massive distribution of printed advertising materials" through low-budget advertising and possible sales promotion actions".

John outlines the steps that should lead to developing strategic steps in building PR in an organization:

1. Analysis of public attitudes to the organization.

2. Analysis of the status of the information obtained.

3. Assumptions for potential problems, needs and possibilities.

4. Elaboration of tactics of procedure, plan for improving attitudes of groups

5. Implementation and feedback [1, p. 224].

The values, presented by the institution are often not enough to successfully build a good image. It is a long-term process, in which the marketer must be aware of the longer-term operation with specific goals. Continuous processes of strengthening the brand through a good image should be followed by audience development and product sales [6].

This leads to the segmentation of the public into different audience categories. Through in-depth analysis, marketers are able to create special strategies for applying various tools of the communication mix.

Positive public relations organizations can also develop during various other external phenomena, caused by cultural, social or other factors. The position of cultural institutions can thus contribute to an even more positive perception of "artistic values" and thus support the survival of more difficult times for the population in the form of artistic experiences.

Among the most current threats, facing almost all countries of the world, was the coronavirus. The strong impact of the spread of the disease has affected the lives of all people. Restrictions on movement, mandatory quarantines of potentially infected people or measures in the form of wearing veils in public spaces have forced the population to leave their homes only to a small extent. Some cultural institutions dealt with this situation in their own way and organized activities to support the arts through online broadcasts by filling out their free time for people. Cultural products in the form of live performances by symphony orchestras, the free 
broadcasting of world-renowned operas and making the jewels of world literature available by several libraries have strengthened the idea of bringing artistic experiences to the public, despite the unfavorable situation in several countries. The Metropolitan Opera in New York published a different title of the opera every day through an audio-visual recording, which opera lovers could enjoy for free. Each title was made available for 20 hours to reach as many people around the world as possible, regardless of time zones [7]. The art gallery, in the form of a digital gallery, was realized by the Italian gallery Uffizi, its "fight against coronavirus art". To the public via the social network Facebook, it presents a gallery, called Uffizi's Decameron with the greatest works of art by world authors [8].

The Slovak public medium RTVS, incorporated into the program works from compulsory literature in the form of films, is intended mainly for graduating students.

In a fact, PR in traditional form was transfored into digital way in very shortly time, when websites, social medias became the only ways how to communicate with cultural consumers. Cultural organizations in Slovakia responded on this period quickly and effectively according to their needs and needs of their audiences.

\section{Content analysis}

\section{From the real to the virtual world}

The primary change on the part of organizations was to use tools in the online way under the given quarantine conditions. Online marketing has gained full strength and organizations have had to deal with an unconventional form of communication with their audience. Social networks, websites and streaming media have become a central communication channel between cultural organizations and the audience.

\section{1. PR of theatres during the pandemic period Slovak National Theatre (SND)}

The charm of theatrical performances lies in the live performance of the actors on the stage in real time at a real place. Theatres had to give up this idea and accept the available options for transferring the theatrical cultural experience directly to the living rooms of their visitors.

At present, Slovak National Theatre, producer of professional theatre in Slovakia, before the pandemic situation intensively reflected Slovaks needs of social and cultural life and took over this function even now. The Slovak National Theatre, as one of the first cultural institutions, took a measure to cancel performances for an unspecified time by the Ministry of Culture and the Ministry of Health of the Slovak Republic. Managers and the SND Marketing Center involved all three components - opera, ballet and drama - in the realization of online content. The director of the Slovak National Theatre commented for the daily news SME said: "We sew curtains in workshops and at home, we've come up with some new formats that we've realized in online forms - you can find them on our site or on YouTube-and we're working on different scenarios as we go about the length of the epidemic and financial possibilities" [9].

The dialogue between the SND and the public has been open since the beginning of the pandemic. Communication was focused mainly on:

1. Cultural activities of SND for spectators in the online form during the pandemic.

2. Official announcements of the situation about pandemic.

3. Requesting support from loyal visitors and the public.

4. PR activities - how SND helps during a pandemic.

The Slovak National Theatre naturally took the opportunity to create the „SND at home” project more than a week after the measures were taken. Used the potential of its own "personalities", whose activities on social networks authentically created content in the various form, - "as I spend my days in quarantine" - that represent soloists of the SND Ballet, or reading of fairy tales, performed by drama actors. In this context, it leads to describe artists as microinfluencers, who present themselves, but also the image of the institution.

The next step of the organization was to support the idea of spreading art through online platforms. Slovak national theatres published several titles for free on Youtube channel. 
"Viewers can look forward to warm-ups with the SND ballet, SND podcasts, an afternoon coffee program with the SND Drama, educational videos based on discussion and recordings of some productions (with the SND drama), short concerts by musicians and singers or reading for children" [10]. Other components of the SND also contributed their activities and skills in the fight against coronavirus. Tailors from art and decoration department sewed a face mask for all SND employees and handed over a certain number of SNDs to those, who take care of public health. Workers also prepared face masks for the most risky group - seniors, to whom the Theatre staff immediately packed a magazine, published by the Slovak National Theatre called the Portal. Two days later, employees also donated their face masks to the Children's University Hospital in Bratislava. Through its actions, the Slovak National Theatre spreads the reputation not only of a cultural institution, but also strengthens its supporting function in critical and crisis situations of the whole society. As an excellent marketing step, we also perceive the addition of the magazine Portal to seniors, who in these times of limited movement in nature will use the opportunity to read the jubilee issue, dedicated to 100th anniversary of Slovak National Theatre.

The Theatre also reacted very promptly to the possible financial crisis after these unexpected, but destructive financial outbursts for the cultural institution. It challenged the audience to have the opportunity to submit a "lifebuoy" for supporting the Theatre in the following forms:

- Do not claim payment for cancelled performances.

- Support the operation of the SND with $2 \%$ of taxes.

- By visiting Theatres, galleries, supporting art after making available to the public.

They supported the campaign on the social network Facebook, where viewers can add a "lifebuoy" frame to their profile, which made the institution seek to share this support more faithfully.

\section{Košice Theatre}

The Košice Theatre, like the Slovak National Theatre communicates with its audience through social networks and a website. However, a special act belongs to the Košice Theatre, specifically to the chief conductor of the opera - Vinicius Kattah, by presenting opera art via social networks. He set up a page on Facebook, called "Forever Opera", which explains to the public the history and details of major operas with audiovisual content, published on Youtube [11]. The project is in English with a choice of subtitles in English, Norwegian, Slovak, Spanish and Portuguese, so the interpretation is theoretically available not only for Slovaks, but also for foreign fans of operas. The realization of individuals - professionals in their field through new media reflects the need for self-realization and spreading awareness of the more difficult genre to the public.

\section{2. Museum and galleries during the pandemic period}

\section{Museums and galleries}

Galleries and museums are another specific group in the cultural field that are in the group of endangered organizations. Exhibited paintings and other exhibits lose their admirers and the value of works of art is isolated from society in enclosed buildings. The subject of their activities in recent weeks has been to create a space for the presentation of works of art at a distance and online.

\section{Slovak National Gallery}

Like most organizations, the Slovak National Gallery, with its extended workplaces throughout Slovakia, closed the gallery on exactly 10 March under the instruction of the Ministry of Culture of the Slovak Republic. Since then, the gallery has been working on a plan to strategically launch the institution in a virtual way. The activities that the employees presented to the public mainly concerned social networks, web portals and video portals - Youtube. "Through our Facebook, Instagram, newsletter and the new upcoming section of the website, in addition to online collections, we will bring you home videos, interviews, but also virtual excursions, which will bring you closer 
to past and in time upcoming exhibitions" younger and older age groups, including families with children through educational projects.

The content is mainly focused on:

- Educational activities for children and youth - e. g. Professor accompanies the hamster with art

"We have also prepared instructions on how to creatively entertain or teach something to your children and yourself in your living room, and we will also offer reading that will make a long time more enjoyable. We will offer the curious from the world of art in the new series "Seven Things About...", which are being prepared by our curators, as well as colleagues from other SNG departments" [12].

- Articles on current topics - e. g. paramedics in the arts.

- Creative activities for young and adults (Handmade production of simple jewelry, ornaments, etc...).

- Virtual gallery tour.

The Slovak National Gallery called the project "Slovak Substitute Gallery", which operates temporarily, at the time of the closed gallery. At the same time it is an excellent opportunity to build the content of the gallery in the online way.

\section{Slovak Philharmonic orchestra}

The Slovak Philharmonic orchestra became a pioneer in the use of streaming content on the Internet long before the pandemic began. Management created a digital concert hall, in which presents several successful projects directly from the redoubt through video recordings. The general director of the Slovak Philharmonic orchestra, Marian Lapšanský came up with the idea of online broadcasts as early as 2007 and the platform works until today. "When I returned from Finland in 2007, I came up with the idea of broadcasting our concerts online, because I was very impressed when I saw their digital concert hall there. The Minister of Culture was very enthusiastic about my idea and also contributed financially to the introduction of Internet broadcasting. We have had a digital concert hall for ten years" [2]. The Philharmonic thus overtook several cultural organizations that were preparing to operate online, but did not consider it to be the primary form of presentation of their cultural products. As part of its competitive advantage, this step of the Philharmonic is attractive, as it already has a base for its audience, and at the same time the creators have avoided quick, operational solutions to get their artistic events into people's living rooms during a pandemic. The stream operates on the portal www.stream.filharmonia.sk and the channel is supplemented by interesting concerts even during the closed gates of the Philharmonic, under the title "Concerts without an audience". "The Slovak Philharmonic wants to enrich the offer of cultural enjoyment of the music-loving public during the coronavirus pandemic with its Concerts without an Audience, but also to support artists, whose current measures have deprived of the opportunity to perform" [13].

They also created a virtual invitation for spectators for individual concerts, which they published via the Youtube platform. At invitations acts artists directly invite the audience to the concert. However, online broadcasting of this kind is demanding for artists due to the concentration of their performance, realized without the audience in terms.

\section{Conclusion}

As a result of the new measures, the view of cultural life has also changed. The pandemic separated the audience from the culture in the real world, but at the same time cultural organizations approached them in the virtual one. Culture in Slovakia did not end, on the contrary the pandemic situation opened new gates for organizations in addressing their audience. Despite economic and social challenges, they have developed in new forms in the digital age. It is clear, that a staging in a theatre, a painting in a gallery, or a live concert will not replace online broadcasting for consumers, but it is an alternative place that needs to be innovated in view of new trends in the media. The question is, if organizations will actively continue their virtual activities or their potential will be reduced by the traditional way, like before. 


\section{References}

[1] Johnová, R. (2008). Marketing kultúrního dědičství a umění. Prague: Grada Publishing, 288.

[2] Tench, R., Yeomans, L. (2009). Exploring Public Relations. Financial Times, 696.

[3] Pravdová, H. (2015). Manažment \& marketing v kultúrnych inštitúciách. University of Comenius in Bratislava, 129.

[4] Světlík, J. (2016). Marketingová komunikace VŠPP. Praha, 335-352.

[5] Hoyle, H. L. (2002). Event Marketing: How to Successfully Promote Events, Festivals, Conventons and Expositions. New York: Wiley, 256.

[6] Rhine, A. (2018). Theatre Management. London: Maxmillan Publisher, 263.

[7] Murphy, Ch. (2020). The Metropolitan Opera will stream operas for free in wake of coronavirus. Available at: https://www. vulture.com/2020/03/coronavirus-the-metropolitan-opera-to-stream-free-operas.html

[8] Ballová, D. (2020). Naživo zo štúdia, divadlo a knihy na Instagrame, virutálna prechádzka galériou. Kultúra žije na sociálnych siet’ach. Denník N. Available at: https://dennikn.sk/1801877/nazivo-zo-studia-divadlo-a-knihy-na-instagrame-virtualna-prechadzka-po-galerii-kultura-zije-na-socialnych-sietach/?ref=suv

[9] Alexová, J. S. (2020). Riaditel' SND: všetko sme mali vypredané. Po zatvorení strácame stotisíc týždenne. Available at: https://kultura.sme.sk/c/22371649/riaditel-snd-peter-kovac-vsetko-sme-mali-vypredane-po-zatvoreni-stracame-100-tisictyzdenne.html

[10] Tasr (2020). V rámci projektu SND v utorok (24.3.) sprístupnilo pôvodnú slovenskú hru Leni autorskej dvojice Valerie Schulczovej a Romana Olekšáka. Available at: https://www.teraz.sk/kultura/slovenske-narodne-divadlo-je-spolu-s/455296-clanok. html

[11] Juhanová, D. (2020). Slovenské operné divadlá a hudobné inštitúcie fungujú v krízových režimoch. Available at: https:// operaslovakia.sk/slovenske-operne-divadla-a-hudobne-institucie-funguju-v-krizovych-rezimoch/

[12] SNG (2020). Projekt Slovenská náhradná galéria. Available at: https://medium.com/sng-online/projekt-slovensk\%C3\%A1-n\% C3 \%A1hradn\%C3\%A1-gal\%C3\%A9ria-1e414cd20d89

[13] Vongrej, L. (2017). Hudba nás harmonizuje a kultivuje. Available at: https://operaslovakia.sk/marian-lapsansky-hudba-nasharmonizuje-a-kultivuje/

[14] Koncerty bez publika (2020). Available at: https://www.webnoviny.sk/koncerty-bez-publika-2/ 